\title{
Time in Spirituality
}

\author{
ADAM RYBICKI \\ The John Paul II Catholic University of Lublin \\ adam.rybicki@kul.pl, ORCID: 0000-0002-2417-6225
}

\begin{abstract}
The article addresses aspects of time in the context of selected aspects of Christian spiritual life. Spirituality is associated with an identification and formation of attitudes, therefore the article is an analysis of some elements of a proper Christian attitude towards time. The first element is a Christian understanding of time as both chronos and kairos. The second dimension of a Christian attitude, defined by the biblical words 'sleep' and 'watch', relates to watchfulness or vigilance as the best form of spending one's time. The third aspect of a Christian attitude is based on the three dimensions of time - past, present and future - in relation to Christian spiritual life. The last part of the article is devoted to perseverance, which is the greatest challenge given to every Christian during the time allotted to them on earth. In the conclusion, the Christian experience of time shows its originality and theologically rooted wisdom.
\end{abstract}

Keywords: spirituality, time, vigil, persistence

Christian spirituality is the path of broadly understood spiritual maturation. The relation between the process of getting mature and the category of "time" has a dual dimension. On the one hand, various aspects of adulting (cleansing, the development of virtues, knowing yourself and God, etc.) are extended in time. On the other hand, the process of personality and spiritual development is characterised by a change of one's attitude towards time. Although the old descriptions of the stages of spiritual development did not yet speak about this aspect of spiritual maturity (here the exception is the emphasis of the inevitable end of human life), the present reflection on spiritual maturity does not ignore this issue. Also, in contemporary spiritual literature the topic of the Christian attitude towards time has been discussed in many contexts. This is obviously associated with the current perception of the transitoriness of time, rush, the overload of activities, stress, and consequently, the need for a wise as it is now defined - time management. Paul-André Giguère positions one's attitude towards time (next to self-reliance, experience, the importance of social roles) among the four most important constant values of spiritual and personality maturation. Summarising the particular stages of a maturing man who is increasingly more aware of the passing of time and its irrevocability, and also his responsibility for time spent on earth, Giguère uses the term "balance of spirit" related to reconciling with "the end of one's own time" - death. ${ }^{1}$

1 Giguère, Dorosły człowiek, 26. 
Contemporary theological-spiritual reflection can even formulate such concepts as the "Christian spirituality of time" or the spirituality of "Christian time." As Wilfried Stinissen has stated spirituality introduces us into "Christian time" in the sense that the acceptance of the faith in Christ introduces man, in the spiritual dimension, into a completely "new time," a new experience of time. This means that the present reflection must not only refer to time "in general" but also to the "Christian time" that impels us to break with experiencing time in the pagan way in line with St Paul's admonition to leave the past - "Formerly, when you did not know God, you were enslaved to beings that by nature are not gods" (Gal 4:8), and to spend the present with a completely different hierarchy of values - "Now, however, that you have come to know God, or rather to be known by God, how can you turn back again to the weak and beggarly elemental spirits? How can you want to be enslaved to them again?" (Gal 4:8-9). Paul refers to ancient astrology, which distinguishes between favourable and unfavourable days, and indicates that "a new time" begins for a Christian, a time in which natural elements will no longer be indicators of prosperity, but God's reign will become the most important reference point and God will become the Lord of all reality. ${ }^{2}$ This distinction between "general" and "new" time is not so easy since these are not separable realities. However, the specific "spirituality of time" as "a new today" is already indicated by the New Testament direction given by the author of the Letter to the Hebrews, summarised as "exhort one another every day, as long as it is called 'today" (Heb 3:13). The New Testament "spirituality of the new time" also includes such elements as the awareness of being always led by the Holy Spirit (Rom 8:14), the sense of time as a gift of salvation (2 Cor 6:3), giving thanks as the best form of using your time (especially in the Eucharist and the Liturgy of the Hours) as well as hope as an attitude towards the future. ${ }^{3}$

As spirituality is closely related to the identification and formation of attitudes, the present paper aims at analysing the Christian attitude towards time (at least some of its elements), an attitude that results in certain requirements for someone who decides to follow the path of Christian perfection. Here are questions that arise for Christians: What is the meaning of the passing of time? What is time, especially in relation to three categories: the past, the present and the future? How should believers live and realise the message of the Gospel in time? These kinds of questions were raised from the beginning of the Church as evidenced by the issues addressed in the earliest New Testament writings. ${ }^{4}$ Yet, today these problems are becoming increasingly more pressing. On the one hand, the multitude of possibilities and the intensity of experience discourage people from confronting such issues, and on the other hand, it is these phenomena, returning with redoubled strength, that make

Stinissen, Eternity in the Midst of Time, 47.

Siemieniewski, "Czas," 156.

Bielecki, Chrześcijanin i czas, 8 . 
people who live "extremely busy" lives feel anxious and tormented. The primary source of the current reflection on the "spirituality of time" is the teaching of Christ, but it must also be admitted that the teaching of Saint Paul regarding the functioning of Christians in the world has a special role as the Apostle of the Nations deliberates on certain issues. His letters frequently refer to the category of time as a specific gift and a task for man who lives in the flesh and in the world.

Further, essentially ignoring the historical aspects, this paper is also based on the present teaching of the Church, on the reflections of contemporary spiritual writers and theologians, and its goal is to show the results of these reflections on the subject in question.

\section{The Spirituality of chronos and kairos}

The spirituality of time means Christians' right attitude towards two ways of understanding time in Greek: chronos and kairos. Although both terms appear in the New Testament teaching related to spirituality, only the meaning of kairos (as the time of God's salvific action) conveys a special challenge to stay awake, to pray, and to fulfil other spiritual and moral requirements. Therefore, the broader meaning of chronos and the intensively explored theology of both terms will be omitted here. ${ }^{5}$ According to Rom 3:26 in the present kairos, God "justifies the one who has faith in Jesus." So the first and most important aspect of the teaching about kairos is spiritual life as justifying the action of three theological virtues: faith, hope and love. It is in Romans 5:1-11 that faith (vv. 1-2), hope (vv. 2-5), love (vv. 5-8) and kairos (v. 6) are described. Paul reflects on the Christian virtue of hope in 8:18-30, indicating that hope faces the nuisances of the present kairos. ${ }^{6}$ This fragment allows us to notice the following characteristics of a Christian's spiritual identity in the context of the aforementioned terms:

- A Christian knows (or should know) chronoi and kairoi, i.e. he perfectly knows and discerns between various times: those that are empty, fruitless, lost and not leading to salvation and those that convey a fundamental meaning for his or her salvation.

- In the eschatological context, i.e. facing the "kairos of the day of the Lord" a Christian knows that the day of the Lord will come like a thief in the night. Therefore, it will be an event that will take place unexpectedly and its inevitability cannot raise the slightest doubt for any Christian.

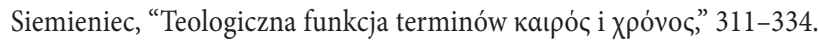

Bielecki, Chrześcijanin i czas, 85-86. 
- A Christian knows that living his or her present kairos is not living in darkness but belonging to the sons of light and the sons of the day. However, the adherence to the sons of light and the sons of the day alone cannot bring any passive complacency to a Christian's life. It means that a Christian completely gets rid of a carefree and irresponsible lifestyle, breaking with indifference and the lack of commitment as to the requirements of faith. ${ }^{7}$

- The specificity of the Christian's kairos results in requirements whose characteristics are included in the phrase hôs mê occurring five times and is rendered as

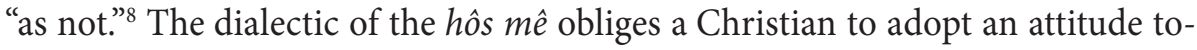
wards earthy realities that would show strong involvement on the one hand, and well understood distance on the other. Obviously, the necessary distance towards worldly realities marked in Paul's "as not" should be related to the required, intensive involvement since for the Christian kairos is a time to take a definitive decision. Neglecting this decision is treating the salvific time as kenos (empty, futile). The characteristic elements of kairos (challenges, unique opportunities, the necessity of taking decisions, and responsibility) make the spirituality of kairos ethical and moral because not using kairos is evil. This element testifies to the originality of Christian spirituality since it happens that in other spiritual traditions the relationship: spirituality (and even mysticism) - ethics is not very close or it does not exist at all. ${ }^{9}$ Utilising or wasting time on earth, perhaps even before it becomes an element of spirituality, is principally an ethical problem that contemporary man may not even recognise. Christian spirituality does not exist without ethics, which can clearly be seen in the use of time: is it not worth restoring the issue of using time to the ethical and moral discourse? Looking at the long and varied history of Christian spirituality, you can discern some rejection of ethics, for example, in several versions of gnosis, but the nihilism of gnosis resulted from its vision of man stressing that people should try everything and have absolute freedom, and only those ethical experiences that are devoid of ethical evaluations could enable people to gain the mystical knowledge of spiritual realities. These versions of Christian gnosis should include the Carpocratians and the Cainites from the second century AD. The Carpocratians proclaimed that the true knowledge of God (gnosis) is achieved only by those who reject all laws (this idea was fought, among others, by Saint Irenaeus of Lyons). ${ }^{10}$ Another example of the rejection of ethics in mysticism was Quietism, a movement initiated by the works of Juan Falconi, Miguel de Molinos and François Malaval in the 17th century: the word quies adopted by this religious movement means

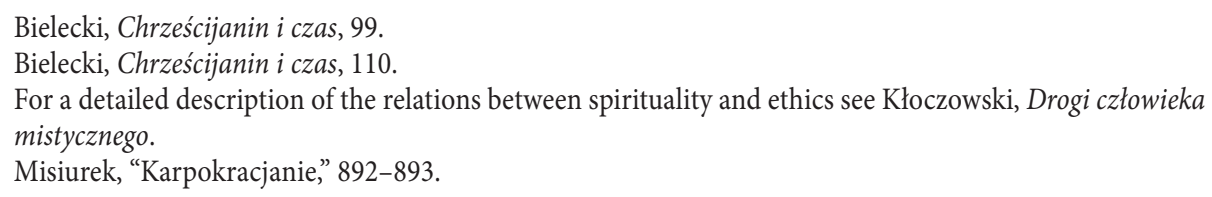


quiet. The Quietists claimed that in order to achieve the heights of spiritual life, you do not have to deal with your own weaknesses and sinful nature, you do not need to ask yourself ethical questions (e.g. Do I use my time well?). What counts is the infused contemplation, while ascetic effort and ethical dilemmas are just obstacles in contemplation. ${ }^{11}$ The moral dimension of the Christian "spirituality of time" is stressed by the fact that what allows us to discern kairos among events of life includes wise reflections, which must not be blinded by passions nor delayed by laziness. On the other hand, all virtues make it easier for us to recognise kairos. ${ }^{12}$ The spiritual-ethical dimension of the good use of time extends to eschatology, and consequently, it requires the virtue of hope. The exhortation of Rom 13:13 "let us live honorably" is followed by "as in the day," and here the day means the eschatological day of the Lord.

- Referring to the Christian's erroneous attitude towards time, one of the contemporary Benedictines associates the failure to discern kairos with the blasphemy against the Holy Spirit. He justifies this connection quoting the words of John Paul II from the encyclical on the Holy Spirit, in which the Pope defines closing oneself up to the action of the Spirit as "the radical refusal to be converted," which in turn means the refusal to come to the sources of Redemption remaining "always" open, in every "now" in the economy of salvation. The one who persists in closing oneself up in sin prevents God's salvific workings in time: "This is a state of spiritual ruin, because blasphemy against the Holy Spirit does not allow one to escape from one's self-imposed imprisonment and open oneself to the divine sources of the purification of consciences and of the remission of sins." ${ }^{13}$ Accordingly, Włodzimierz Zatorski claims that the sin against the Holy Spirit is "to close yourself up in chrónos and not being open to kairós." ${ }^{14}$ Another aspect of our wrong attitude towards "time" is not to see God's presence and workings in the past. Saint Paul, wanting to deepen his exhortation to become open to kairos, introduces an interesting category: the term "others" (loipoi), meaning those who do not understand or do not want to understand kairos and its requirements. They are still in hoi chronoi, with all the consequences resulting from this fact. "Others" are enslaved to the elemental spirits of the world (Gal 4:1-4) $)^{15}$ and have no hope; their reaction to the day of the Lord is an illusory sense of security (Gal 5:2). They spend time using it as the sons of darkness and the sons of the night (Gal 5:5-7) and inevitably move towards what is contained in the concept of $\operatorname{orge\hat {e}}$ (wrath; cf. Gal 5:9). ${ }^{16}$ The introduction of the category of "others"

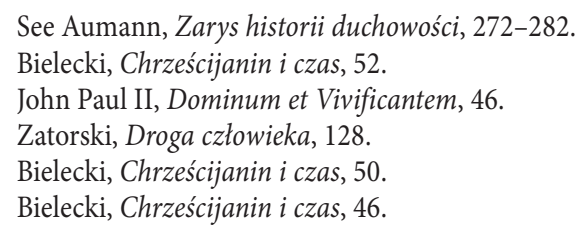


into the spiritual preaching may only be a certain pedagogical procedure, but it can also be treated as underlining the total novelty, originality and distinctness of the Christian ethos as well as a particular approach to the issue of time.

\section{Using Your Time: "fall asleep" and "stay awake" in the Context of Spiritual Life}

In Saint Paul's teaching, a believer as "the son of light" and "the son of the day" (1 Thess 5:5) is called not to use his time "sleeping" but "keeping awake." At this point, "staying awake" should not be understood as something passive or stative, but as a certain movement, a kind of "inner setting off." ${ }^{17}$ Thus it is worth reflecting on the attitude of "staying awake" in contemporary Christian spirituality.

Watchfulness as exercising caution against daily temptations. Occupying one's time with staying awake should extend to the whole of the Christian life. Its external manifestation is to be the struggle against daily temptations, a fight anticipating the great eschatological battle. The Gospels show Jesus as the best model of this kind of watchfulness, especially in times of temptation, a model that is more visible considering that the disciples, being not sensitive enough to their master's instruction, fell asleep. "Stay awake and pray that you may not come into the time of trial" (Matt 26:41) is not about a particular temptation, but about all loss of faith and doubt. That is why the admonition to stay awake in "time" goes beyond the framework of Gethsemane and is directed to Christians of all times. Constant vigilance protects against this kind of doubt. The call to occupy one's time with watchfulness is repeated many times in the apostolic letters (1 Cor 16:13; Col 4:2; Eph 6:10-20). One of these admonitions is formulated in a particularly meaningful way, and maybe that is why it was put in the text now read every evening in the Liturgy of the Hours, in the Completorium: "Discipline yourselves, keep alert. Like a roaring lion your adversary the devil prowls around, looking for someone to devour" (1 Pet 5:8). Here, just like in Eph 6:10-12, the enemy is clearly indicated. This kind of keeping alert is especially recommended to all superiors who carry out responsibility for a certain community: they are to watch over not only themselves but over others, and they are to defend the entire community against "savage wolves" (Acts 20:28-31).

Watchfulness as praying all night. In Eph 6:18 and Col 4:2, Paul might have referred to the practice of the early Christian communities that kept alert praying. Watchfulness is a concrete realisation of Christian vigilance and following what Jesus already did. Today pastoral activities addressed to young people often take the form of vigils of prayer, adoration, etc. Those initiating such events rightly refer to Christ 
and the Apostles praying at night as well as to ascetics, the Fathers of the Church and early Christian writers who recommended and praised this practice as extremely spiritually fruitful. In Poland, an interesting phenomenon of such a practice is vigils of prayer in the Jasna Góra Chapel of the miraculous image. This place is visited by various groups of pilgrims who are registered. In previous years, some of them asked about the possibility to stay in the chapel for a whole night. But at present almost every night of the year there is a vigil of prayer organised by a pilgrims' group. This information, of course, may show an increased number of groups arriving at Jasna Góra, but it may also indicate that pilgrims to a greater extent include vigils of prayer in programmes of their pilgrimages.

Watchfulness as being ready to greet the coming Lord. In the synoptic Gospels, watchfulness is the main command Jesus gave to his disciples in his concluding speech showing the end-time things and the coming of the Son of Man (Mark 13:33-37): the coming of the Son of Man will be so unexpected as the coming of a thief in the night (cf. Matt 24:43-44) or a master of the house returning home at midnight without letting his slaves when he will come (cf. Mark 13:35-36). Therefore, believers should not be overcome by sleep, but should keep alert, i.e. remain watchful and always be ready to receive the Lord. According to Marcel Didier, watchfulness is a characteristic of the spirituality of a disciple who living in hope, awaits the return of Jesus; this implies the necessity of renouncing pleasures and earthly goods (Luke 21:34-36). ${ }^{18}$ In Paul's letters, which strongly emphasise the eschatological perspective, especially in 1 Thess 5:1-7, the echo of the gospel admonitions to stay awake - the antonyms katheudein (to sleep) and grêgorein (to watch) - has been rooted deeply in Christian spirituality. This can also be seen nowadays as some prayer meetings are called "vigils of prayer." Looking at grêgorômen (let us keep awake), we can list the following aspects that it contains: awareness of the Lord coming as a judge, a certain kind of tension in awaiting him, unwavering persistence in keeping alert despite the delayed Parousia as unpredictable and inevitable, decision to go out to meet the Lord with joy and hope instead of waiting for something that will unavoidably come, arousing fear.

"Watchfulness" is dynamic; it is about moving, setting off. ${ }^{19}$ It requires one to be active and put on the spiritual armour of God: "let us be sober, and put on the breastplate of faith and love, and for a helmet the hope of salvation" (1 Thess 5:8). It is worth recalling that also in the Book of Revelation, the teaching of the Judge of the Last Times directed to the Church of Sardis is an urgent call for vigilance (Rev 3:1-3) because this Church has spiritually "fallen asleep," i.e. forgetting that Christ will come again, it has stopped waiting for him. If the believers of the Church of Sardis do not wake up, the Lord will come like a chief, and "blessed is the one who stays awake

18 Didier, "Czuwać," 192-193.

19 Bielecki, Chrześcijanin i czas, 79-80. 
and is clothed" (Rev 16:15) as only him will be invited to join the triumphal march of the Lord. ${ }^{20}$ Therefore, the watchfulness that occupies the time of the Christian life on earth, as a natural consequence of faith on the day of the Lord, is a distinctive element of the Christian ethos.

Watchfulness (alertness) as metaphysical awakedness. Dietrich von Hildebrand drew attention to two types of spiritual awakedness: the first dimension consists in receiving and accepting what is most important from all reality, the other type implies insisting on the general situation of being in everything that is experienced, seeing everything in the perspective of finality, the fundamental truth. ${ }^{21}$ The philosopher also points to various degrees of this "awakedness within the awareness of responsibility," i.e. the phase of the intensity of the possibility of understanding and penetrating the surrounding reality:

1. The first phase is a fundamentally and general act of turning towards the world of values and its ideas. It concerns not only spirituality, but also opening to ideas rooted in works of art or the beauty of nature. ${ }^{22}$

2. The second stage means opening up to moral values, to the implacable earnestness of their demands, which leads to the brightening of the metaphysical situation of man, i.e. makes him aware that he can utter "no" or "yes" in response to moral values. ${ }^{23}$

3. Hildebrand's third level of awakedness is directly related to God, so it is strictly religious alertness. Defining it as readiness to venture into the world of God's mysteries the author cites the figures of the Old Covenant patriarchs or Saint John the Baptist, who "heard and understood" what God spoke to them. ${ }^{24}$ Maintaining such awakedness simultaneously consists in accepting grace and starting a life of prayer, and, what is worth emphasising, getting to know oneself more deeply. In this context Saint Augustine's call Noverim te, noverim me $!^{25}$ becomes the quintessence of the definition of this type of awakedness. In addition to the desire to know God and his works, this kind of awakedness is an internal opening and allowing God's light to shine through so that one recognises and finds oneself in this light. ${ }^{26}$

The ethical-moral dimension of watchfulness: conscience. John Paul II spoke about watchfulness during his pilgrimages to Poland in 1983 and 1991, referring to the words of the Jasna Góra Appeal. He said that the attitude of being awakened primarily refers to conscience if it is not blurred or distorted. Watchfulness is work-

\footnotetext{
Didier, "Czuwać," 193.

Hildebrand, Liturgie und Persönlichkeit, 89.

Hildebrand, Liturgie und Persönlichkeit, 89.

Hildebrand, Liturgie und Persönlichkeit, 90.

Hildebrand, Liturgie und Persönlichkeit, 91-92.

Augustine, Soliloquia II, 1,1 (PL 32, 885).

Hildebrand, Liturgie und Persönlichkeit, 93.
} 
ing on our conscience, on developing what is good in me and making efforts to eradicate evil.

What does it mean, "I watch"? It means I make an effort to be a person with a conscience. I do not stifle this conscience and I do not deform it. I call good and evil by name, and I do not blur them. I develop in myself what is good, and I seek to correct what is evil by overcoming it in myself. This is a fundamental problem which can never be minimised or put on a secondary level. [...] "I watch" also means I see another. I do not close in on myself, in a narrow search for my own interests, my own judgements. "I watch" means: love of neighbour; it means: fundamental interhuman solidarity. ${ }^{27}$

The interesting thread of watchfulness was also taken by the Polish Pope in 1991. "I watch" most frequently had a personal dimension (I watch over myself), but the Pope broadened the meaning of this biblical exhortation to teach what it meant to watch over others. "I am watchful expresses the attitude of the Mother. Her life and her vocation are expressed in being watchful. She keeps watch over men and women from the first moments of their existence. Her keeping watch is accompanied by sadness and by joy. "When a woman is in travail she has sorrow, because her hour is come; but when she is delivered of the child, she no longer remembers the anguish, for joy that a child has been born into the world. The words are those of Christ himself. Mary's maternal watchfulness, what a profound experience this is! What a message mysteriously inscribed in the heart of a woman who lived completely for God!"28 Therefore, the spirituality that leads believers to spend their time in a good way is modelled on Mary watching not so much over herself but over Christ and consequently, over the Church.

27 Jan Paweł II, "Rozważanie wygłoszone do młodzieży," 210-211. This citation comes from the speech addressed to youth gathered for the appeal at Jasna Góra (18 June 1983). The official translations are available in Italian and Portuguese at http://www.vatican.va/content/john-paul-ii/en/travels/1983/ travels/documents/trav_polonia.html [access: 10.07.2020]. Its official Italian version goes as follows: "Che cosa vuol dire: "veglio"? Vuol dire: mi sforzo di essere un uomo di coscienza. Non soffoco questa coscienza e non la deformo; chiamo per nome il bene e il male, non li offusco; elaboro in me il bene, e cerco di correggermi dal male, superandolo in me stesso. Questo è un problema fondamentale, che non si potrà mai sminuire, né spostare su un piano secondario. [...] Veglio vuol dire inoltre: vedo un altro. Non mi chiudo in me, nella stretta cerchia dei miei propri interessi, dei miei propri giudizi. Veglio vuol dire: amore del prossimo; vuol dire: fondamentale solidarietà interumana."

28 [John Paul II], Discorso di Giovanni Paolo II durante la veglia di preghiera a Częstochowa. 


\section{Categories: Past, Present and Future vs. Spiritual Life}

The famous statement by Hans Urs von Balthasar that "spirituality is the subjective side of dogmatics" or "dogmatics in action" finds confirmation in relation to three categories of time: the past, the present and the future. ${ }^{29}$ According to W. Stinissen, the three basic dimensions of time correspond to the Three Persons of the Holy Trinity: the past is equivalent to the Father, the future is connected with the Son (gathers together into one the children of God [John 11:52], will come to judge the living and the dead), while the present is the same union of the future and the past as the Holy Spirit unites the Father and the Son. Thus the Holy Spirit in the present spiritual life of Christians becomes the "rule" of this life; the Spirit gives inspiration, specifies the tasks entrusted by the Father and gives them flexibility by adapting them to the circumstances present at the given time. We can therefore speak of a kind of circumincessio (mutual interpenetration) of the three categories of time, just as theology talks about the circumincessio of the Three Divine Persons. ${ }^{30}$ The dogmatic basis of spiritual life, referring again to the above statement by H.U. von Balthasar, will be expressed in the fact that the Trinitarian spiritual life will simultaneously comprise all the three dimensions of time:

Past. In the perspective of "Christian time," the past should not be a destructive category in spiritual life causing alienation or regret. If that were the case, a person would not experience his or her full freedom: if the past were lived in such a negative way, it would become a compelling force, certainly more or less determining. Why is this happening and why this kind of spiritual experience of the past is an original element, i.e. one that immediately allows us to recognise Christian spirituality? As shown by W. Stinissen referring to the Carmelite mystics, this is related to Christians' acceptance of the unlimited manifestation of God's mercy, which is most fully revealed in forgiveness. Accordingly, for example Teresa of Ávila and, even more frequently, Thérèse of the Child Jesus write about "les misericordes du Seigneur"31 (here a plural form - "the mercies of the Lord"), and so they emphasise a series of acts of mercy that cover the equally long chain of sins and weaknesses that occurred in the past. It is this spiritual idea of the "mercies of the Lord" over the past human weaknesses and sins that allows Stinissen to establish the grounds for proposing the term "Christian memory," which means that the past should be thought of more in the light of these great "mercies" than of sins and weaknesses.

Now: the present moment. In contemporary reflection on the Christian spiritual life, the point of reference is the teaching of the Church Fathers (Saint Augustine) or other Christian saints (Saint Teresa of Ávila, Saint Thérèse of Lisieux, Saint Fran-

\footnotetext{
Balthasar, Verbum Caro, 227.

Stinissen, Eternity in the Midst of Time, 56.

Thérèse de Lisieux, Histoire d'une âme, 4.
} 
cis de Sales). Against the background of this orthodox, Catholic teaching, one can sometimes see elements of the erroneous attitude of the so-called "spiritual inaction," i.e. Quietism. It negated active asceticism, verbal prayer, meditation conducted by means of natural strengths and saw perfection only in a passive inner attitude. Similar extreme views now and then emerged within Hesychasm in the Eastern Orthodox Church and Protestant piety. The subject of "spirituality of the present time" became even more relevant in the times of the 20th century existential anxiety, permeated by the sense of uncertainty, new threats and doubts. Therefore, the Catechism of the Catholic Church reminds us that praying the Lord's Prayer every day we recollect this aspect of faith: "«today» also expresses confidence [...] this «today» concerns not only our time that is subject to death: it is God's «today»" (2863). And so the Catechism combines the subject of the present moment with the theme of "trust, joyous assurance" (2778) resulting from the certainty of being loved, but it does not reduce trust to passive waiting, but to actively participate in the transformation of the existing world. The theme of "living in the present moment" is also analysed in the spirituality of many ecclesial Catholic movements (Chiara Lubich and Focolare, Renewal in the Holy Spirit). ${ }^{32}$

Future. The specificity of Christian spirituality is expressed, among other things, in the fact that "a Christian does not go towards the future, but the future comes to him" ${ }^{\prime 3}$ because the Kingdom of God draws closer to people (cf. Matt 1:15). This reversal of the perspective of perceiving the future is anchored in the eternal "today" of God who comes to man. The distinction between futurum and adventus, which Stinissen proposes, consists precisely in the fact that futurum is the future of the secularised man as the fruit of his own actions, while adventus refers to the future that comes from God like the city of Jerusalem "coming down out of heaven from God" (Rev 21:10). Since Christians understand this future (contained in the eternal present of God) as forgiveness, pardon, God's fathering us into his children, they can think of future in an optimistic way: looking forward to achieving the fullness of life rather than seeing future as something dangerous or even frightening. ${ }^{34}$

\section{In Praise of Endurance}

Paul's warning against weariness: "let us not grow weary in doing what is right" (Gal 6:9) is eschatological; formed in different ways, it often appears in the New

\footnotetext{
32 Siemieniewski, "Chwila obecna," 134.

33 Stinissen, Eternity in the Midst of Time, 55.

34 Stinissen, Eternity in the Midst of Time, 55.
} 
Testament, especially in the context of awaiting the Parousia. ${ }^{35}$ Moreover, Paul states that "suffering produces endurance (hypomonên), and endurance produces character (dokimên), and character produces hope (Rom 5:3b-4). The term hypomonê means "patient endurance" and often occurs in the context of suffering and adversities. Spending one's time should be marked by patient endurance that produces "character," and the one who endures adversities becomes dokimos, i.e. a man of unyielding character. ${ }^{36}$ Also, the phrase "we suffer with him" (Rom 8:17) indicates that the suffering of the saved, on account of their relationship with Christ, differs from the suffering of other creatures, and therefore, it should be characterised by special endurance. The term "endurance" defines the way of our waiting for the Lord that should not only be filled with patience and commitment, but also accompanied by willingness to endure the "momentary affliction" (2 Cor 4:17). Endurance is strengthened by the first fruits of the Spirit that Christians have. ${ }^{37}$

In contemporary spiritual literature, it is worth noting a new and promising research phenomenon, namely the distinction between "male spirituality" and "female spirituality." It is in the context of male spirituality that one can note the present update of the Old Testament and New Testament patterns of spirituality for men, also in the aspect of endurance being discussed here. One of the models of male endurance referenced today (to clarify, it is endurance of faith) is Job. ${ }^{38}$ Stu Weber portrays him as a noble man, husband and father, caring for the existence of his family, but the feature that is particularly emphasised in the context of masculinity is stability. Performing many good deeds, Job does not succumb to difficulties and his changeable fate, but continues to do good with an extremely praiseworthy endurance. ${ }^{39}$ In the context of contemporary male spirituality, this feature of endurance is strongly contrasted with the spreading culture of temporality and variability; there is a connection between these phenomena and "mobility," understood broadly and literally..$^{40}$ According to Weldon M. Hardenbrook, 25 percent of the US population change their place of residence every year, which is related to the inability to put roots down and to problems with forming social identity at many levels, including the sphere of spiritual-religious and ecclesial formation. Today, the widely-understood attitude of man towards time has changed; the moral attitude is limited to the category of "sincerity," i.e. a momentary feeling, and any discrepancy between what is done and what is actually felt is perceived as hypocrisy. In such a mentality, any lasting commitment arouses surprise and even suspicion; being systematic causes resentment and is preferred to spontaneity identified with sincerity; "sincerity" thus understood is con-

\footnotetext{
35 Bielecki, Chrześcijanin i czas, 161.

36 Bielecki, Chrześcijanin i czas, 171.

37 Bielecki, Chrześcijanin i czas, 200.

38 Weber, Tender Warrior, 56.

39 Weber, Tender Warrior, 57-63.

40 Hardenbrook, Missing from Action, 82.
} 
sidered the most important value. All kinds of rituals and the arduous repetition of activities become unbearable since they aim at consolidating best habits and skills in man. Therefore, in relation to spiritual life, one can face the danger of the dominance of "the spirituality of enthusiasts." ${ }^{41}$ Enthusiasm is nothing bad in itself, especially when it comes to the original enthusiasm of new converts; enthusiasm returns at important moments, but usually nothing special happens in the Christian life. Jean Louis Bruguès, warning against this kind of approach to time, refers to the novel by Dino Buzzati, entitled The Tartar Steppe, where the password used inside the Fort was "Miracle" and the reply was "Misery." ${ }^{42}$ An extreme exaltation and the search for enthusiasm would turn the Christian life into progressive moments of euphoria ("miracle") and despair ("misery"), which would resemble the mechanism of addiction rather than painstakingly advancing in spiritual development. Therefore, it is again important to emphasise endurance (patience), which allows us to face anxieties and unforeseen events, which allows us to keep our commitments and to maintain our moral and spiritual structure; it is an optimal hint leading us to experience our time in the most Christian way. ${ }^{43}$ Patience should contain three elements: a) motivation - for Christians motivation is the promises of Christ; the infinite possibilities of good and happiness that he has opened for us give meaning to all kinds of patience, ${ }^{44}$ b) a state of mind or serenity understood as self-control sustaining daily hope when there is no noticeable change: "Hence the necessity for a virtue to safeguard the good of reason against sorrow, lest reason give way to sorrow: and this patience does." ${ }^{45}$ c) programme - it is about "controlling" the future, but not in the sense of its development and the course of events, but in the sense of the echo that these events will reflect in us. In case of blows, failures and falls, patience is extremely needed because when we face fears (e.g. Will the next attempt not end in failure again?) patience will give a kind of mental resilience and at the same time will strengthen our hope. Rising again and becoming loyal to Christian principles can also be met with a discouraging response from others. In the face of sarcasm, irony, misunderstanding, especially on the part of loved ones, patience is even more needed, and in this light, it may be said to be one of the most important Christian virtues, which Bruguès formulated in an extremely concise and universal way:

It is transformed into permanence. [...] Through its various manifestations, patience makes us strong. It protects us against being thrown into all types of enthusiasm. [...] It sets us free from the influence stemming from breakdown. It stimulates our bravery; undoubtedly, thanks to patience the word "virtue" also takes on its deepest meaning. It underlies all

\footnotetext{
Bruguès, "Sztuka trwania," 106-107.

Buzzati, Il deserto dei Tartari, 45.

Bruguès, "Sztuka trwania," 107-108.

Bruguès, "Sztuka trwania," 109.

Thomas Aquinas, Summa Theologica II-II, q. 136, a. 1.
} 
confidence: the confidence we place in ourselves and in our endeavours, and also the confidence that others have in us. Patience characterises the attitude that allows us to impose our will on life so that life does not impose its will on us. ${ }^{46}$

\section{Conclusion}

It should therefore be expressly recognised that in the context of the theology of Christian spirituality time appears as a gift (it is in time that necessary changes leading to sanctification, formation, spiritual warfare, etc., take place) and also as a task since a proper or improper use of time results in a manner consistent with the Gospel guidelines or against them. The originality of the Christian approach towards the time we live in is a combination of joy (kairos is the time of saving love) and a grave responsibility. This gravity and responsibility have not only a temporal and existential significance, but also an eschatological one as Christian spirituality leads to an ever-deeper realisation of the need for personal accountability before God. Using the well-known term formulated by H.U. von Balthasar, Christian spirituality leads to the "dramatism" of time and becomes a certain original feature of time one can even say a permanently avant-garde paradigm (way of thinking) for time in the world, in the contemporary world as well.

\section{Bibliography}

Augustine, Soliloquia (PL 32, 869-904).

Aumann, J., Zarys historii duchowości (tł. J. Machniak) (Kielce: Jedność 1993). von Balthasar, H.U., Verbum Caro (Einsiedeln - Freiburg: Johannes 1990).

Bielecki, S., Chrześcijanin i czas według listów św. Pawła (Lublin: Wydawnictwo KUL 1999).

Bruguès, J.-L., "Sztuka trwania," Communio 10/1 (1990) 106-116.

Buzzati, D., Il deserto dei Tartari (Milano: Mondadori 1945).

Didier, M., "Czuwać," Stownik teologii biblijnej (red. X. Léon-Dufour) (Poznań - Warszawa: Pallottinum 1985) 192-194.

Giguère, P.-A., Dorosty człowiek, dojrzała wiara? (tł. A. Rajczyk) (Kraków: Wydawnictwo "M" 1997).

46 Bruguès, "Sztuka trwania,"111: "Przekształca się ona w stałość. [...] Poprzez swe różne przejawy, cierpliwość czyni z nas ludzi mocnych. Chroni nas przed rzuceniem się w wir entuzjazmów. [...] Wyzwala nas spod wpływów załamania. Pobudza do męstwa; niewątpliwie, dzięki niej również słowo cnota nabiera najgłębszego znaczenia. Leży u podstaw wszelkiego zaufania: zaufania, które pokładamy w nas samych i w naszych przedsięwzięciach, oraz zaufania, które inni żywią wobec nas. Charakteryzuje postawę polegającą na narzucaniu się życiu, aby życie nie narzuciło się nam.” 
Hardenbrook, W.M., Missing from Action. Vanishing Manhood in America (Nashville, TN: Nelson 1987).

von Hildebrand, D., Liturgie und Persönlichkeit (Graz - Wien - Köln: Styria 1955).

Jan Paweł II [John Paul II], "Apel Jasnogórski. Rozważanie wygłoszone do młodzieży, Częstochowa 18 czerwca 1983 r.," Jan Paweł II, Dzieła zebrane. IX. Homilie i przemówienia z pielgrzymek - Europa. 1. Polska (Kraków: Wydawnictwo “M” 2008) 209-213.

[John Paul II], Discorso di Giovanni Paolo II durante la veglia di preghiera a Częstochowa, Santuario di Jasna Gora, Mercoledi, 14 Agosto 1991, http://www.vatican.va/content/john-paul-ii/pl/ speeches/1991/august/documents/hf_jp-ii_spe_19910814_vigil-wyd.html [access: 10.07.2020].

John Paul II, Encyclical Letter "Dominum et Vivificantem" on the Holy Spirit in the Life of the Church and the World (1986).

Kłoczowski, J.A., Drogi człowieka mistycznego (Kraków: Wydawnictwo Literackie 2001).

Misiurek, J., “Karpokracjanie," Encykolopedia katolicka (eds. B. Migut et al.) (Lublin: Towarzystwo Naukowe KUL 2000) VIII, 892-893.

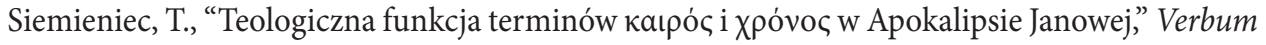
Vitae 35 (2019) 307-342.

Siemieniewski, A., “Chwila obecna," Leksykon duchowości katolickiej (red. M. Chmielewski) (Lublin - Kraków: Wydawnictwo "M" 2002) 133-134.

Siemieniewski, A., “Czas," Leksykon duchowości katolickiej (red. M. Chmielewski) (Lublin Kraków: Wydawnictwo “M” 2002) 156.

Stinissen, W., Eternity in the Midst of Time (San Francisco, CA: Ignatius Press 2018).

Thérèse de Lisieux, Histoire d'une âme (Paris: Librairie Saint-Paul 1911).

Thomas Aquinas, The "Summa Theologica" of St. Thomas Aquinas Literally Translated by Fathers of the English Dominican Province (London: Burns Oates \& Washbourne [n.a.]).

Weber, S., Tender Warrior (Colorado Springs, CO: Multnomah 1993, 1999).

Zatorski, W., Droga człowieka (Kraków: Tyniec Wydawnictwo Benedyktynów 2006). 
